\title{
Modelling price scenarios for sustainable collective action and farm production: pepper in El Roble settlement, Costa Rica
}

\author{
F. Sáenz-Segura ${ }^{1 *}$, R.A. Schipper ${ }^{1,2}$, D. Miranda ${ }^{1}$ and J.M. Chaves ${ }^{1}$ \\ ${ }^{1}$ Centro Internacional de Política Económica para el Desarrollo Sostenible (CINPE), Universidad Nacional de Costa Rica (UNA), \\ P.O. Box 2393-3000, Heredia, Costa Rica; ${ }^{2}$ Development Economics Group (DEC), Wageningen University, Postbus 8130, 6700 \\ EW Wageningen, the Netherlands; fernando.saenz.segura@una.cr
}

RESEARCH ARTICLE

\begin{abstract}
Pepper (Piper nigrum L.) is considered a non-traditional cash crop for enhancing local development in Costa Rica and a suitable activity for small farmers. Trade of pepper has been done by using contractual agreements between producers and processors, which provides at least three functions: insurance, incentives and information. Contracts also require a high level of commitment from contracting parties to keep the equity, efficiency, and sustainability of the trade relationship. The shift of trade conditions from a competitive to a monopsony market encouraged a group of farmers to start an association that aims to bulk and process pepper from members. Breaching contracts by members of the association endanger this effort of sustainable entrepreneurship. This usually happens when temporary market conditions yield higher procurement prices by other competitors. This situation is also worsened by the lack of proper information on production and processing costs between the contracting parties, and then, the disagreement on the procurement price fixation and payment conditions. By using a mixed integer linear optimization model, we aim to identify the 'best' price of fresh pepper traded between both parties. We make use of primary information from 12 different farms on production costs and from the association on processing costs. The model incorporates minimum required net margins for all contracting parties, while modelling the net margins of each party, the amount of traded fresh pepper and preferred contract possibilities, given different fresh pepper price scenarios. At lower prices, some of the farmers that supply pepper, do this to just break-even. At higher prices, more is supplied by more farmers. Under monopsony conditions and individual contracts between parties, it is in the interest of the buyer to offer higher fresh pepper prices in order to buy and process more pepper, up to the point that the marginal costs of buying more pepper are equal to the marginal benefits of that extra pepper. This is because the processor has fixed costs, next to variable costs. Higher volumes reduce the average total costs of processing per kg of pepper, and thereby increase profit. When group contracts are possible, thus under bilateral monopoly conditions - farmers acting as 'one' seller and the processor as the only buyer - more fresh pepper is supplied at higher prices than under monopsony conditions as more farmers would have higher surpluses. At the same time the processor would have a higher profit than using individual contracts.
\end{abstract}

Keywords: monopsony, institutions, collective actions, contract form, fixed and variable production costs, pepper, Costa Rica

Copyright: $\odot 2015$ F. Sáenz-Segura et al.. This is an open-access article distributed under the terms of the Creative Commons Attribution License, which permits unrestricted use, distribution, and reproduction in any medium, provided the original author and source are credited.

(cc) BY-NC-ND

\section{Introduction}

Pepper (Piper nigrum L.) has been produced in the northern region of Costa Rica since the mid-1980s by small farmers. These producers usually live in peasant settlements (asentamientos campesinos in Spanish) created by the State. El Roble settlement was the first place where smallholders started to grow pepper as a cash crop. El Roble lies in the canton of Sarapiquí, between the towns of Puerto Viejo and La Virgen (Figure 1). The farm sizes vary, but do not exceed 50 ha. Given labour constraints, farmers' pepper plots are on average 0.9 ha. Despite the fact that pepper is not an important crop in Costa Rica, it is considered an attractive non-traditional cash crop for enhancing local development. Pepper requires intensive manual plant-byplant care, and a small amount of agrochemicals (fertilizers and pesticides); mechanization is not yet suitable. After the third year, the plant starts producing continually and can 


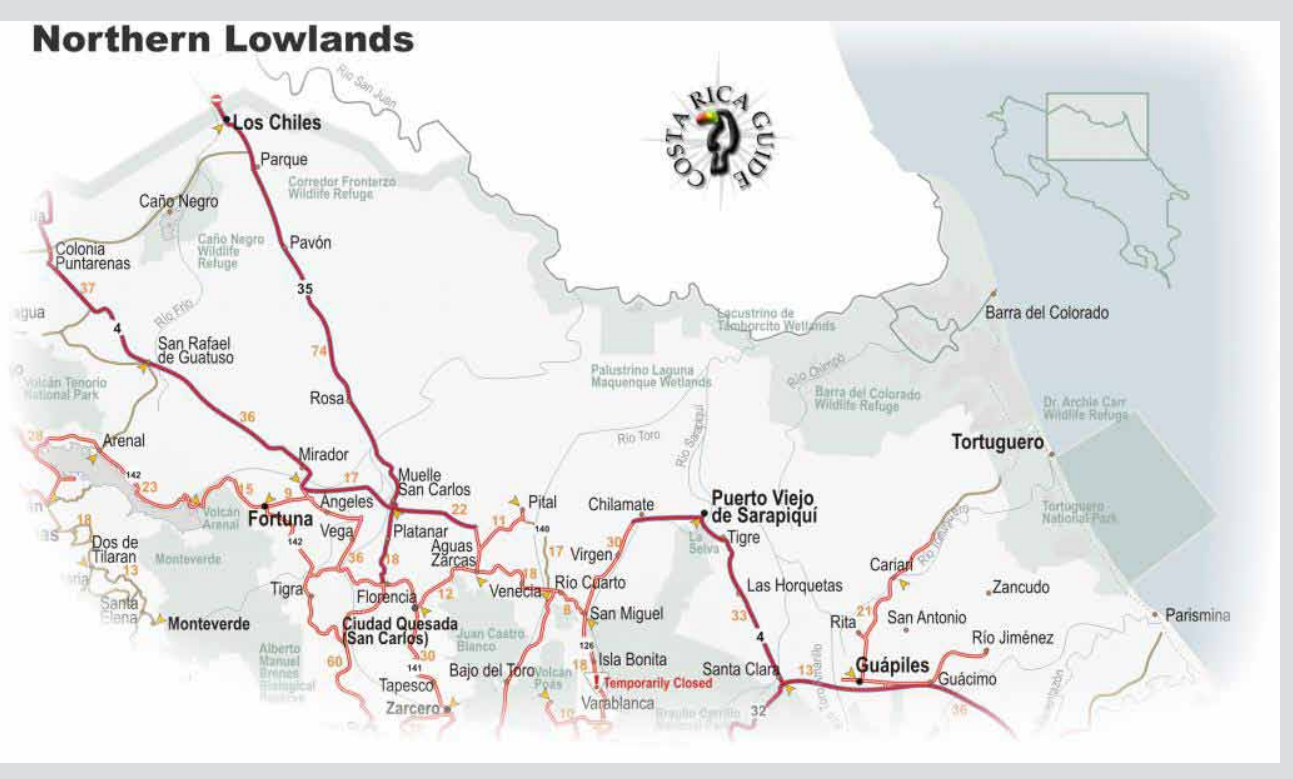

Figure 1. Part of the Northern Region of Costa Rica (source: http://costa-rica-guide.com/travel-map/northern-lowlands.html).

be harvested twice a month. With proper care, the plant life cycle can be 15 years. Therefore, pepper is a suitable crop for small farmers who want to earn an extra income from other activities (Sáenz-Segura et al., 2009).

Spot markets for pepper do not exist in Costa Rica; pepper trading has traditionally been done using contractual agreements between producers and a processor. Usually, pepper is delivered fresh to a processor under certain agreed conditions concerning quality, amount, timing, and purchase price (Sáenz-Segura et al., 2010). The use of an alternative market tool like a contract serves, in principle for both parties, at least three purposes: insurance, incentives, and information. However, a contractual situation also requires a high level of commitment from both parties to maintain the equity, efficiency, and sustainability of the trade relationship (Ruben and Sáenz, 2008).

Over the past 25 years, pepper producers have faced a more competitive market situation (two or more processors), but since 2000 a monopsonistic market situation has prevailed. At that time, one single buyer started to exerts its monopsonistic power by imposing a lower procurement price and a changing set of quality conditions (i.e. variable levels of rejection rates). This situation encouraged a group of farmers from El Roble settlement to start an association, namely APROPISA S.A. In the beginning, this association was aimed to bulk together pepper from members, deal with the monopsonistic buyer as one single seller, and perform an exit-check on the quality of the delivered fresh pepper (Sáenz-Segura et al., 2010). During the past three years, and, after receiving external assistance, the association began to process pepper itself and sell it directly to several agro industries in the capital. With this movement, the association dispensed with the disadvantageous contractual conditions with the monopsonistic buyer and became a new competitor for fresh pepper. Hence, the association started to act as micro agro-enterprise and currently receives fresh pepper from members and non-members alike.

At present, the association is highly regarded by members of El Roble community as a good collective effort, securing a higher procurement price and providing funds for several local development activities (improvement of roads, schools, water supply, etc.). However, the association has so far not been able to recruit more farmers, even inside the same settlement. If the association wants to increase its profits and become a well-developed enterprise, it requires more and more fresh pepper to process. For instance, with its present capacity, the association can handle twice the current amount of fresh pepper. On the other hand, members of the association occasionally sell some of their produce to other competitors, like the former monopsonistic buyer, when the competitor's procurement price is slightly higher.

Breaching contracts on delivering produce is a common and well-documented problem in the contract farming literature (Fafchamps, 2004; Grosh, 1994; Key and Runsten, 1999). Contracts between contracting parties can be breached in various ways, whereby farmers, or the firm, or both 
can deviate from contractual terms. According to Barrett et al. (2011) there are many opportunities for breaching contracts because of the diverse nature of contractual terms, asymmetric information, time lags, and the so-called relationship-specific investments involved in the contractual relationship. Most of these factors within breaching contracts are related to the costs associated with monitoring the contract terms. A typical example in Latin America is when coffee producers deviate from commitments with their organization (association and/or cooperative), and tend to sell their produce partial or totally to a competitor.

Contract breaches by members of an association endanger this attempt at sustainable entrepreneurship. This usually happens when temporary market conditions yield higher procurement prices from other competitors. When market conditions deteriorate, farmers then return to the organization for its support. Farmers seem to assume that the organization will always be there for them. They do not believe that their deviation from the contract will endanger the existence of the organization, even though they have witnessed the failure of many other collective projects.

When market conditions are good, deviating farmers claim that they need more money, thus the temptation to breach the contract (or not to have one) increases. This situation is also made worse by the lack of reliable information on production and processing costs between the contracting parties. The lack of accurate information on production costs at farm level is a common problem amongst small producers, with low educational levels and finite resources.

In this paper we address the 'unknown' fair procurement price problem that endangers the sustainability of the trade relationship between pepper producers and their own entrepreneurial effort. By using a mixed integer linear optimization model, we aim to identify the 'best' price of fresh pepper traded between both parties, under a given contractual regime (group or individual contracts). We make use of primary information from 12 different farms on production costs (individually for each farm) and from the association on processing costs.

The rest of the paper is organized as follows: in the second section we briefly review how contract farming and collective actions aim to achieve sustainable trade relationships and entrepreneurial development. In the third section we specify theory, methodology and data sources. In the fourth section we describe and discuss the major outcomes. We conclude our paper in Section 5.

\section{From basic collective actions and contractual arrangements to sustainable entrepreneurships}

\section{Small producers, contract farming for market integration and collective action}

Rural territories in developing countries have a large population of small family-based production units, which vary in terms of availability and access to productive resources, levels of technology, yields, and managerial skills. These variations mean that some producers are more able to integrate into markets than others. This observation has been defined in the literature as household-specific market failures (De Janvry et al., 1991; Sadoulet and De Janvry, 1995). Moreover, this type of family enterprise also faces other external factors, like input-output market imperfections, and high transaction costs for acquiring information, and for negotiating and enforcing exchange arrangements (Upton, 1996). These drawbacks are also present in mid-income countries like Costa Rica. Therefore, small family-based producers tend to value risk-reduction strategies more than profit (Ellis, 1988; Ruben et al., 1994; Sadoulet and De Janvry, 1995) As a result, they look for institutional devices with which to acquire a degree of certainty regarding market information, delivery conditions and procurement prices (Sáenz-Segura, 2006a).

Over the past 20 years, contract farming has been mentioned in the literature as a reliable institutional mechanism for overcoming - or at least reducing - these market and information failures, and for providing a kind of 'safe zone' for a sustainable trade relationship between small producers and a given buyer. In this sense, contract farming has been regarded as a good institutional tool to reduce farmers' risk averseness, in particular for those in the initial phase of nontraditional agro-production. On the other side, the buyer would also be assured of a continuous supply of product, at the right time, under certain quality conditions, and at the required amount (Carney and Watts, 1990; Glover, 1984, 1987; Gow et al., 2000; Grosh, 1994; Key and Runsten, 1999; Ruben and Sáenz, 2008; Singh, 2002). Even though some other authors have warned against the adverse effects of contracts due to exclusion of small producers and their unequal bargaining opportunities (Glover and Kusterer, 1990; Grosh, 1994; Little and Watts, 1994; Porter and Phillips-Howard, 1995; Rickson and Burch, 1996; Siddiqui, 1998; Torres, 1997), in practice, a wide variety of contractual arrangements are likely to coexist, where firms specify the type of contract and conditions according to location, type of product, type of producers, and contract enforcement possibilities (Barrett et al., 2011). On the other hand, 
smallholders may be able to negotiate different delivery conditions, according to their particular interests (Key and Runsten, 1999).

Research conducted in Costa Rica in two sectors (pepper and chayote) showed that the use of a market tool like a contract serves for both parties (producer and buyer/processor) at least three purposes: insurance, incentives and information. However, a contractual arrangement also requires a high level of commitment from both parties to maintain the equity, efficiency, and sustainability of the trade relationship (Ruben and Sáenz, 2008). In other words, contract farming cannot be regarded as an ideal market mechanism, or a final solution in itself, but as an arrangement that has to be continuously adjusted (or re-negotiated) by the contracting parties.

In the case of the pepper sector, the buying/processing part often exerted its monopsonistic power to the point of endangering a sustainable trade relationship with producers. Next to the change in contract conditions for delivery and rejection rates, the lack of accurate information on pepper production costs from both the producers and the processor, yielded the most sensitive point of disagreement: a 'fair' procurement price between parties.

According to Welsh (1997), one possible way to counteract an unbalanced bargaining power like the one previously described, is to promote and strengthen producers' organizations, such as cooperatives, associations, boards of producers, networks, etc. These organizations are the most common and most likely collective action institution to cope with an imbalance in market power. Collective actions have been recognized in the literature as a good way of strengthening small producers' bargaining power and providing access to input and output markets. Collective action is regarded as a good policy instrument for development by governments and private NGOs (Paumgarten et al., 2012), as they improve the operation of a given market chain, create new forms to market new products, enhance community participation and improve the distribution of benefits amongst members of the collective effort (Devaux et al., 2009; Faure et al., 2011; Knoeber, 1983; Kruijssen et al., 2009). The most common forms of collective action in Costa Rica are cooperatives, producers' associations, corporations (public-private hybrid organizations), industrial chambers and peasants' unions (Le Coq et al., 2014). A basic producer association or cooperative may start with a few activities (i.e. organizing the delivery of produce) and progressively become a larger entrepreneurial effort. It is expected that such an evolution from a basic collective action up to an inclusive entrepreneurial effort yields social benefits to producers as members of the organization, their families and the community in general. The final result can be a communitybased formal enterprise performing inclusive business, with sustainable supply chain development.

The transition from basic collective actions to a formal enterprise performing a more sustainable business model is not easy in developing rural territories. Currently, collective actions are vulnerable at their early stage of performance. The heterogeneity of a farming population and the usual conflict between individual and collective interests are amongst the most common problems. In terms of trade and business, small producers tend to put their own interests before their organization's interest (Glover, 1987; Rickson and Burch, 1996; Singh, 2002). This is particularly true in cases where new settlers' communities emerge from the implementation of land reform programs, such as in the El Roble settlement, where people coming from different regions of the country, with different cultures, are living together and bound to conduct communal projects.

\section{Pepper production and processing in El Roble settlement, including efforts towards collective action}

Contract pepper farming has been studied in Costa Rica since 2000, when a first national survey of 63 producers was performed (El Roble settlement included). At that time, there was a spatially fragmented market: monopsonistic in some regions and more competitive in others. The results of that research showed limited effects of contracts regarding access to inputs, yields, and productivity. Furthermore, formal contracts were mostly endorsed by incomeconstrained farmers at the early stages of their plantations. However, in subsequent phases, or under more competitive market conditions, producers shift to verbal commitments and tend to breach contractual arrangements. Moreover, when a monopsony prevails, yields tend to be lower (SáenzSegura, 2006b, 2009).

In a second stage, two modelling exercises were performed focusing on contract choice, with survey data gathered amongst pepper producers from El Roble settlement, between 2000 and 2001 (19 active producers in total). At that time, there was a prevailing monopsony, while pepper producers from $\mathrm{El}$ Roble started a collective action institution, in the form of an association, namely APROPISA S.A. A non-linear integer model was designed, with two contract choices, two seasons and two types of opportunistic behaviour. The model maximizes both the firm and 
producers' $^{\prime}$ income $e^{1}$ under three scenarios: monopsony, monopoly and joint profit maximization. The objective was to model those market situations, in which collective action amongst farmers is profitable for both the farmer and the firm, even when the farmers' bargaining power increases to the disadvantage of the firm. The model included seasonal contracts and endogenous pricing. Furthermore, all model versions were based on one average farm producing pepper, and one single monopsonistic buyer (Sáenz-Segura, 2006c, 2009; Sáenz-Segura et al., 2010).

As stated before, by the year 2010 APROPISA S.A. began to process pepper itself and sell it directly to several agro industries in the capital. In so doing, the association dispensed with the disadvantageous contractual conditions from the monopsonistic buyer and started to act as a micro agro-enterprise. The new processing firm currently receives fresh pepper from members and non-members alike. These micro, small and medium enterprises (MSME) ${ }^{2}$ (abbreviated according to the Spanish acronym MIPYMES) are very common in Costa Rica, representing $90 \%$ of the industry sector, and generating $46 \%$ of total employment and 30\% of the GDP (INEC, 2012) .

As mentioned in the introduction, even though APROPISA is well regarded by members of the community as a good collective effort, the association has not been able to recruit all pepper producers from the settlement. After performing a preliminary consultation with some members and nonmembers of the association, we realized that most of them are uncertain about a 'fair' procurement price, given their ignorance about their own production costs.

\footnotetext{
${ }^{1}$ Producers' income from selling fresh pepper to the processing firm, and the firm's income from selling processed pepper elsewhere.

${ }^{2}$ There are many different definitions and criteria for classifying micro-enterprises worldwide. Level of employment, annual sales, and level of assets are the most commonly accepted variables (Guaipatín, 2003; OIT, 2009). The International Labour Organization defines and classifies micro and small enterprises according to the amount and stability of labour they sustain (OIT, 2009), while the International Development Bank prefers a mixed approach between number of employees, capital investment and annual sales (Guaipatín, 2003).

${ }^{3}$ In Costa Rica this important industry sector is regulated by law $N^{\circ} 8262$, which classify MIPYMES and defines lines of action for its promotion and reinforcement.
}

\section{Objective and main research question of paper}

In this paper we provide a modelling exercise on the best contract scenario based on one common proxy for producer's welfare: farm profits (Barrett et al., 2011). We focus on producer's income from selling fresh pepper, leaving out other sources of household income. Furthermore, we take into account the association's income as a proxy of the collective action welfare. Moreover, any assessment of 'a good income' is necessarily based on a good estimation of the costs one faces. However, such estimates are not usually available among producers in Costa Rica. The lack of reliable information on production and processing costs of pepper by APROPISA and its supplying producers, is currently one of the biggest drawbacks for sustainable entrepreneurship and chain integration. For that reason we conducted a 'cost of production' survey in 2012 among pepper producers and collected data about transaction and processing costs (data referring to one year's operation: 2011).

We aim to create a model to see which type of contract between the producers of pepper and the processor, and which price, would ensure an optimal supply of fresh pepper, i.e. leading to the highest processor income in conjunction with a high common income for the producers. As explained before, if APROPISA wants to increase its profits and evolve into a well-developed enterprise, it requires more and more fresh pepper to process (according to the APROPISA manager, they are able to process about twice the current amount). Elements to consider in this interaction are the market form, production, transaction and processing costs, and individual or collective (group) contracts. The main question that we address in this respect, given the specific conditions regarding fresh pepper production and processing in El Roble in 2011, is 'What fresh pepper price is the best from the point of view of the producers as well as the processor?' We refer to this price as the 'best price'.

An optimization model on contract choice helps to identify those price scenarios, where different parties can reach sustainable agreements.

\section{Theory, methods and data}

\section{Theory of monopsony and bilateral monopoly}

The market for fresh pepper in El Roble in 2012 could be seen as a monopsony, as there are some 25 to 50 farmers that produce fresh pepper every year, while there is only one main buyer, namely the APROPISA S.A. According to the economic theory of a monopsony, the price of the commodity that a monopsonist buys is not given, 
but depends on the quantity he buys; the more he buys, the higher the price according to the supply curve of this particular commodity (in our case this commodity is fresh pepper which is used as an input for processing black pepper). The profit of the monopsonist will be highest at the point that the marginal revenue is equal to the marginal costs (first-order condition). Furthermore, the second-order condition for profit maximization requires that the rate of change of the value of the marginal product of the input will be less than the rate of change of the marginal costs of the input (see, for example Henderson and Quandt, 1980: 191). Another important restriction of the monopsony situation is that in order for a farmer to produce the commodity, a minimum requirement is that he gets such a price that he can operate without making a loss (or generate a minimum income). Similarly, the processor would only be willing to buy the commodity if he is able to generate a minimum income or, at least work on, or beyond, the break-even point of his operations.

In the case of a bilateral monopoly, meaning one seller and one buyer, the situation is more complicated (Henderson and Quandt, 1980: 222-225). However, in the particular situation of El Roble settlement, for a bilateral monopoly to occur, it would be necessary for the association of the producers, APROPISA (as a buyer of fresh pepper), to be confronted with another association of the producers as a seller. This is not the case.

It is important to note the differences between a theoretical monopsony and the present case. One modification to the strict monopsony situation that occurs in the particular case of this paper is that the association might work with two types of contract, individual contracts with one producer, or group contracts with several producers (or, maybe, with all producers). The latter type of contracts might result in mutual benefits to sellers and buyer, i.e. by reducing transaction costs and improving the quality of the commodity. The other deviation from a strict monopsony situation is that the producers can always opt not to sell to the buyer/processor, but to a third party outside the settlement; however, in that case he will receive a price that is lower than the price he would have received if he had sold the product to the monopsonist.

\section{Model definition}

Our model definition addresses the general research question in this research: what is the 'best price' for fresh pepper traded between sellers/producers and a buyer/ processor, and under which contractual arrangement? The model includes data from 12 different seller/producers (already selling fresh pepper; see below), each with farmspecific production costs (variable \& fixed) and a minimum required net margin (in view of alternative income or the opportunity costs of family labour). From the processing part we included production costs (variable \& fixed), the price of processed pepper (black pepper), and a minimum required net margin. Both producers and the processor aim to maximize their respective net margins.

The present model is a mixed integer linear optimization model with an objective function maximizing the joint income of the buyer (processor) and the sellers (producers), weighed according to their market power under different market and contract conditions (Equation 1, see Appendix 1). The model calculates the gross and net margins of the buyer and the sellers (Equations 2-6), takes into account the minimum net margin requirements of the buyer and the sellers (Equations 7-8), and the fresh pepper production capacity restrictions of the sellers (Equation 9). The model forces integer contract choices (one contract type) during a certain period (Equations 10-11). See Appendix 1 for the mathematical formulation.

\section{Data collection}

The survey in El Roble, carried out in 2012, was held while not knowing the exact population of pepper producers inside the settlement. This has been a common situation since our first visit in 2000. Usually pepper producers get into or out of the activity, depending on pepper market conditions, their interest in other agricultural and nonagricultural activities, or just because people die or retire with nobody else to take up the activity. There are also newcomers to pepper production. Nobody inside or outside the settlement keeps records of this mobility of producers. We started with a list provided by APROPISA that estimated a total of somewhere in the range of 25 to 50 producers inside the settlement. This list soon proved to be very inaccurate in the field. Therefore, we visited each plot, checking for active producers, either in their early stages of establishing the plantation, or those already producing and selling pepper. Using a 'snow-ball' approach, we ended up with a list of 21 active producers to whom we gave a questionnaire (Sánchez and Chavez, 2012: 3). All of the producers claimed to be associated with APROPISA at the time of the interview. From this population only 12 were able to provide complete and consistent data on their plantation establishment, production and harvest costs. As stated before, a common problem amongst smallholders in Costa Rica is the lack of farm household records, and thus, ignorance about production costs. 
Six major categories of variables were included in this questionnaire: plot localization, farm and household characteristics, production and market variables, contractual regimes, market and information problems, and a detailed systematization of production costs (Sánchez and Chavez, 2012: 2 and Annex 2).We also performed a systematization of costs for the processing facility of APROPISA. All data refer to 2011, while the costs correspond to one year of operation.

\section{Modelling scenarios}

With the model we simulate different scenarios concerning the possible contract forms that the parties involved might prefer. Table 1 shows the two types of possible contracts between the parties and the four possible outcomes.

If both parties prefer individual contracts (outcome A), a contract can be concluded. This has specific consequences for the price and quantity of fresh pepper traded between a farmer/seller and the buyer/processor. The same applies if both parties prefer a group contract (outcome D). If both parties cannot agree on the contract form (outcomes B and C), the farmer/seller can sell his fresh pepper to a third party at a discount. In this case the buyer/processor cannot purchase the fresh pepper.

In the present paper we consider two scenarios: (1) only individual contracts are possible; and (2) both individual and/or group contracts are possible.

\section{Results}

\section{Production costs at farm level (fixed and variable costs)}

Actual production costs per $\mathrm{kg}$ of fresh pepper depend on the one hand on the age and plant density of the pepper plantation, and the related establishment cost, including labour, and on the other hand, on the annual expenses for inputs and labour. As explained before, based on our survey in El Roble, we could only adequately establish the production costs for 12 of the 21 farmers interviewed. The reason was that only 13 had pepper trees old enough (more than 2 years) to produce pepper, while one of these 13 farms was not able to provide data on the production of pepper. Some details about these 12 farms are shown in Table 2.

As can be seen in Table 2, production costs differ considerably between farms. So far, it is not clear why there are such differences in production costs (columns 9-12). In the survey production costs were requested for the area of the plantation as indicated in column 4 . Using the stated production in 2011 (column 6), production costs per kg were estimated. At first sight, factors like number of trees (column 2), age (column 3), area with pepper (column 4), or tree density (column 5), do not explain cost differences ${ }^{4}$. Another possible factor might be the role of family labour and how family labour is valued by each family; this will be explored in more detail below.

\footnotetext{
${ }^{4}$ Nor, for that matter, yield differences, e.g. per ha (column 7) or per tree (column 8).
}

Table 1. Two types of contracts between a seller and a buyer. ${ }^{1}$

\begin{tabular}{|c|c|c|c|c|c|}
\hline \multirow[t]{2}{*}{ Type of contract } & \multirow[t]{2}{*}{ Seller } & \multirow[t]{2}{*}{ Buyer } & \multirow[t]{2}{*}{ Contract? } & \multicolumn{2}{|l|}{ Consequences for } \\
\hline & & & & Seller² & Buyer \\
\hline A & IC & IC & YES & pf_A $A^{*} Q \_A$ & pf_A* $A_{-} \_A$ \\
\hline B & IC & $\mathrm{GC}$ & NO & pf_B*(1-discount $)^{\star} Q \_B$ & No purchase \\
\hline c & $\mathrm{GC}$ & IC & NO & pf_C*(1-discount $)^{*} Q_{-} C$ & No purchase \\
\hline $\mathrm{D}$ & $\mathrm{GC}$ & $\mathrm{GC}$ & YES & pf_D*Q_D & $p f \_D * Q \_D$ \\
\hline
\end{tabular}

${ }^{1} \mathrm{IC}=$ Individual contract; $\mathrm{GC}=$ Group contract.

${ }^{2}$ pf_X $=$ price of fresh pepper per $\mathrm{kg}$ under possibility $X(A, B, C$, or $D) ; Q_{-} X=$ quantity of fresh pepper traded in $\mathrm{kg}$ under possibility $X(A, B, C$, or $D)$. 
Table 2. Fresh pepper production characteristics and costs of production (survey in El Roble, 2012).

\begin{tabular}{|c|c|c|c|c|c|c|c|c|c|c|c|}
\hline 1 & 2 & 3 & 4 & 5 & 6 & 7 & 8 & 9 & 10 & 11 & 12 \\
\hline 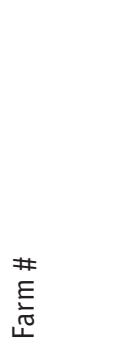 & 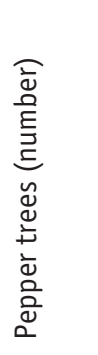 & 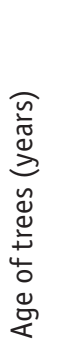 & 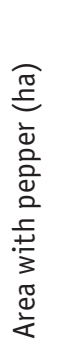 & 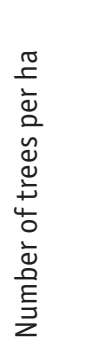 & 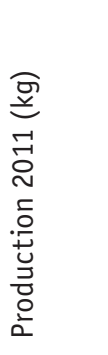 & 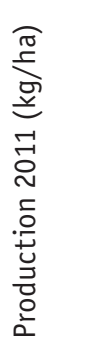 & 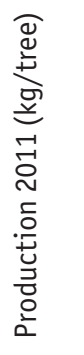 & 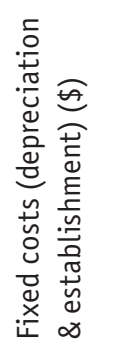 & 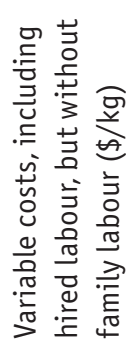 & 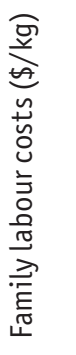 & 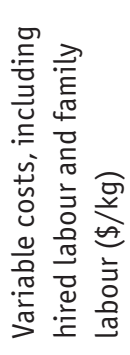 \\
\hline Farm01 & 400 & 2.0 & 0.25 & 1,600 & 2,800 & 11,200 & 7.0 & 91.57 & 0.26 & 1.14 & 1.39 \\
\hline Farm02 & 1,600 & 12.0 & 1.50 & 1,067 & 10,000 & 6,667 & 6.3 & 209.56 & 0.87 & 0.01 & 0.88 \\
\hline Farm03 & 1,500 & 15.0 & 1.50 & 1,000 & 2,400 & 1,600 & 1.6 & 120.11 & 0.31 & 1.02 & 1.33 \\
\hline Farm04 & 2,000 & 4.0 & 1.00 & 2,000 & 7,036 & 7,036 & 3.5 & 194.94 & 1.35 & 0.30 & 1.64 \\
\hline Farm06 & 450 & 2.0 & 0.25 & 1,800 & 6,000 & 24,000 & 13.3 & 101.13 & 0.67 & 0.45 & 1.12 \\
\hline Farm07 & 1,650 & 1.5 & 1.00 & 1,650 & 8,750 & 8,750 & 5.3 & 243.44 & 0.05 & 0.47 & 0.52 \\
\hline Farm08 & 2,250 & 16.0 & 0.75 & 3,000 & 8,500 & 11,333 & 3.8 & 226.18 & 0.11 & 0.69 & 0.81 \\
\hline Farm13 & 1,200 & 9.0 & 1.00 & 1,200 & 13,120 & 13,120 & 10.9 & 96.69 & 0.15 & 0.54 & 0.70 \\
\hline Farm16 & 2,000 & 2.0 & 1.50 & 1,333 & 10,920 & 7,280 & 5.5 & 134.76 & 0.15 & 0.98 & 1.13 \\
\hline Farm17 & 1,000 & 5.0 & 0.50 & 2,000 & 3,200 & 6,400 & 3.2 & 31.38 & 1.20 & 0.09 & 1.29 \\
\hline Farm19 & 7,500 & 10.0 & 3.00 & 2,500 & 9,690 & 3,230 & 1.3 & 346.93 & 0.43 & 1.04 & 1.47 \\
\hline Farm20 & 1,600 & 5.0 & 1.00 & 1,600 & 600 & 600 & 0.4 & 209.73 & 2.84 & 5.79 & 8.63 \\
\hline Average & 1,929 & 7.0 & 1.10 & 1,729 & 6,918 & 8,435 & 3.6 & 167.20 & 0.70 & 1.04 & 1.74 \\
\hline
\end{tabular}

\section{Production costs as used in model}

Using the cost and production data of the survey (Table 2), but assuming a recommended plant density of 1,089 trees/ha, planted at $3 \times 3 \mathrm{~m}$, as well as good husbandry, a yield plateau of $11 \mathrm{~kg}$ of fresh pepper per tree per year ${ }^{5}$ was used to establish the maximum production capacity of each farm, given the existing area of the plantation (Table 3).

\footnotetext{
${ }^{5}$ With 1,089 trees/ha and $11 \mathrm{~kg} /$ tree, this means $12,979 \mathrm{~kg}$ fresh pepper per ha. This upper limit is high and more than is reported in most references regarding black pepper agronomy and production. It is well above the average production per tree observed in the survey (3.6 kg/tree; median $4.6 \mathrm{~kg} /$ tree; range $0.4-13.3 \mathrm{~kg} /$ tree; based on column 8 in Table 2). Universidad EARTH (2007) documents a maximum yield of $9.7 \mathrm{~kg} /$ tree, based on research in the Dominican Republic, while Sivaranam et al. (1999) report highest yield in Thailand of 2,918 kg of black pepper per ha; converted to fresh pepper this would mean $9,717 \mathrm{~kg} / \mathrm{ha}$, implying, with 1,089 trees $/ \mathrm{ha}, 8.9 \mathrm{~kg} /$ tree. As we are interested in production possibilities here, we take the average production per tree of the three producers that have the highest yields. Their weighted mean is between 10.5 and $10.7 \mathrm{~kg} /$ tree; we use a rounded figure of $11 \mathrm{~kg} /$ tree.
}

In this table farms are listed according to increasing total costs of production per $\mathrm{kg}$, based on model calculations, using the situation of individual contracts (column 9). The production costs in Table 3 differ slightly from those in Table 2, as additional contract-specific transaction costs were included.

In column 2, the above-mentioned maximum production capacity for pepper is presented. In column 3, the fixed part of the production costs is shown. It consists of the annual depreciation of the equipment used and the investment for establishing the pepper plantation, corrected for inflation. In columns 4, 5 and 6, one can observe the variable cost of production per kg of fresh pepper. Column 4 shows the costs for inputs and hired labour. In column 5, the costs of family labour are presented; these are estimated using the number of days of family members doing pepper-related tasks valued at the wage that each family pays for hired labour. In column 6 , the total variable costs are presented (sum of columns 4 and 5).

In columns 7-9, total costs of production per $\mathrm{kg}$ of fresh pepper are presented, thus the total of the variable costs 
Table 3. Fresh pepper production characteristics and costs of production (Survey in El Roble, 2012).

\begin{tabular}{|c|c|c|c|c|c|c|c|c|}
\hline 1 & 2 & 3 & 4 & 5 & 6 & 7 & 8 & 9 \\
\hline 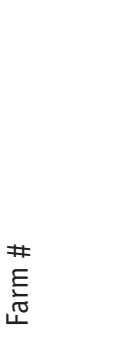 & 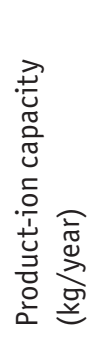 & 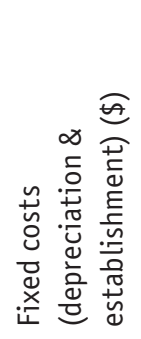 & 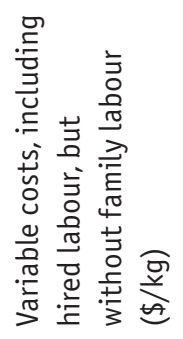 & 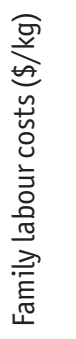 & 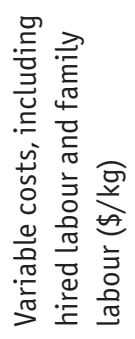 & 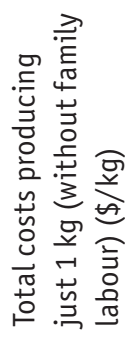 & 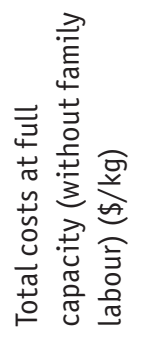 & 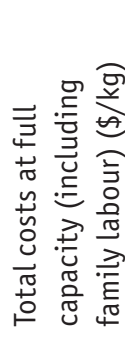 \\
\hline Farm07 & 11,979 & 243.44 & 0.05 & 0.47 & 0.52 & 243.96 & 0.07 & 0.54 \\
\hline Farm13 & 11,979 & 96.69 & 0.15 & 0.54 & 0.70 & 97.38 & 0.16 & 0.70 \\
\hline Farm08 & 8,984 & 226.18 & 0.11 & 0.69 & 0.81 & 226.99 & 0.14 & 0.83 \\
\hline Farm02 & 17,969 & 209.56 & 0.87 & 0.01 & 0.88 & 210.44 & 0.88 & 0.89 \\
\hline Farm16 & 17,969 & 134.76 & 0.15 & 0.98 & 1.13 & 135.89 & 0.16 & 1.14 \\
\hline Farm06 & 2,995 & 101.13 & 0.67 & 0.45 & 1.12 & 102.25 & 0.71 & 1.16 \\
\hline Farm17 & 5,990 & 31.38 & 1.20 & 0.09 & 1.29 & 32.67 & 1.20 & 1.30 \\
\hline Farm03 & 17,969 & 120.11 & 0.31 & 1.02 & 1.33 & 121.44 & 0.32 & 1.34 \\
\hline Farm01 & 2,995 & 91.57 & 0.26 & 1.14 & 1.39 & 92.96 & 0.29 & 1.42 \\
\hline Farm19 & 35,937 & 346.93 & 0.43 & 1.04 & 1.47 & 348.40 & 0.44 & 1.48 \\
\hline Farm04 & 11,979 & 194.94 & 1.35 & 0.30 & 1.64 & 196.58 & 1.36 & 1.66 \\
\hline Farm20 & 11,979 & 209.73 & 2.84 & 5.79 & 8.63 & 218.35 & 2.86 & 8.64 \\
\hline Average & 13,227 & 167.20 & 0.70 & 1.04 & 1.74 & 168.94 & 0.72 & 1.76 \\
\hline
\end{tabular}

and the fixed $\operatorname{costs}^{6}$. To include the latter one has to make an assumption about the quantity of production. The quantity can vary between nothing (zero) and production at full capacity. As zero production would lead to infinite fixed costs of production per $\mathrm{kg}$, in column 7 the costs of production for producing just one $\mathrm{kg}$ of fresh pepper are presented, excluding family labour costs. In columns 8 and 9 , two versions of the total cost of production per kg at full capacity are presented; in column 8 excluding family labour costs and in column 9 including family labour costs.

As with the use of the survey data only (Table 2), the simulated costs of production (Table 3 ) also vary considerably between different farms, for example, the lowest is $\$ 0.54$ per $\mathrm{kg}$ of fresh pepper, while the highest is $8.64 \$ / \mathrm{kg}$ (Table 3, column 9). At a price of $1.25 \$ / \mathrm{kg}$, for example, only 6 of the 12 farmers would be able to supply pepper without incurring losses. It also shows that the average production cost of $1.76 \$ / \mathrm{kg}$ is rather misleading as it would suggest that pepper cannot be supplied without a loss at this price, while in fact 6 of the 12 farms can obtain a

\footnotetext{
${ }^{6}$ Thus defined, these total costs per kg of fresh pepper are obviously the same as the average costs of production.
}

profit. Obviously, at different fresh pepper prices one would get different results; therefore, the model in this paper is analysed using different prices.

Another important aspect is the costing of family labour. Being a labour-intensive crop, it is important to consider which part of the necessary labour is hired and which part is family labour. The first is paid in cash and therefore has a direct effect on the cash income of the families. Regarding family labour, the actual form of remuneration is not known but is in general not directly in cash and certainly not in full at the going rate. Therefore, families can supply pepper at lower prices without incurring a direct financial loss. Using again a price of $\$ 1.25$, one can observe in column 8 of Table 3 that 10 of the 12 farms have total production costs without family labour of lower than $\$ 1.25$ (the average of this type of production cost is $0.72 \$ / \mathrm{kg}$ ). It is obvious that for any type of decision model regarding the supply of pepper by farm households, as is the model in the present paper, it is important to consider how farm households cost their labour and how this element plays a role in their decision making. 


\section{A new model approach: An assessment of production and processing costs, and fresh and processed pepper prices}

The approach in the present model can best be explained using a market with a supply and demand function analogy. Imagine that in the settlement of El Roble there are pepperproducing farmers, each with different production costs. By arranging the farms according to increasing production costs as in Table 3, one can construct a supply function (see upper part of Figure 2).

Production costs can be defined in different ways. In this case, using data from the survey in 2011 (Table 2), as well as simulated data (Table 3), the farms are arranged according to their total cost of production per kg of fresh pepper (sum of fixed and variable costs), including the costs of family labour (see the squared blue line in this Figure 2); this can be interpreted as the fresh pepper 'supply' function of the 12 producers together. On the other hand, fresh pepper is demanded by pepper processors. Assuming for the time being that there is only one processor, the processor has total processing costs per $\mathrm{kg}$ (sum of fixed and variable costs and including the costs of purchasing fresh pepper); this is the 'demand' function (see dotted pink line; the area below this function represents the total processing costs). Since at low volumes of processing pepper, the fixed costs weigh heavily in the processing costs per $\mathrm{kg}$, this demand function is downward sloping. Given that the processor is the only buyer of fresh pepper, it can establish the purchasing price of this pepper.

In Figure 2, the producer surplus is the area between the line of the fresh pepper price and the supply function. This surplus is positive left of the intersection between the supply function and the price line, but negative right of this intersection. If farmers do not intend to incur losses, the quantity of pepper supplied to the market would be determined by this intersection. In order to reach this intersection, in the model the producer surplus is maximised at different fresh pepper prices (in model these range from 0.95 to $1.70 \$ / \mathrm{kg}$ at steps of $\$ 0.05$; below and above this range there is no feasible integer solution), in order to determine the supply by all farmers that indeed supply at each price, i.e. of those that do not incur a loss (meaning a negative net margin $)^{7}$; see below.

The surplus of the processor is the area between the demand function and the line that represents the selling price of

\footnotetext{
${ }^{7}$ This applies to the particular monopsony market form; in case of a competitive market, the price of fresh pepper would have been determined by the intersection of the demand and supply function.
}

processed pepper (converted into equivalent fresh pepper ${ }^{8}$ ). This surplus is negative left of the intersection between the demand function and the processed pepper price, but positive right of this intersection. Viewing Figure 2, one can conclude that it is in the interest of the processor to buy fresh pepper at low prices, thus lowering the processing costs. However, it is also in his interest to buy as much fresh pepper as possible in order to enlarge the area of surplus to the right. Nevertheless, the quantity supplied to the market by the farmers is determined by the intersection of the supply function according to the costs of production and the fresh pepper price as explained earlier; thus the only possibility to increase the fresh pepper quantity would be to raise the fresh pepper price. A profit-maximising processor would try to establish a price that would lead to a large supply, without increasing the costs of processing too much; in other words he would look for a compromise between a low price and a high volume ${ }^{9}$. In our model, the choice that maximises his profit also depends on the contract form, as that has a bearing on the production and transaction costs. Under individual contracts between each farmer and the processor, the best choice for the processor turns out to be $0.95 \$ / \mathrm{kg}$ of fresh pepper (lowest price used in the model), leading to a net margin of $\$ 43,256$ (Table $4 \mathrm{a}$; at that price the aggregate net margin of the farmers is $\$$ 26,587 , see Table $6 a$, shared by 4 of the 12 farmers, on average $\$ 6,647$ ); however, where group contracts are also possible, the processor would choose a price of $1.20 \$ / \mathrm{kg}$. In this case his net margin is $\$ 47,589$, thus higher than in the case of individual contracts only (Table $4 \mathrm{~b}$ ). At the same time, under group contracts the aggregate net margin of the farmers is $\$ 58,498$ (Table 6b), shared by 6 farmers (on average $\$ 11,539)$. Therefore, under the conditions in this particular case study, introducing the possibility of a group contract creates a win-win situation: higher net margins for more farmers, while the profit of the processor also increases. See below for more detailed results for individual farmers.

The supply function of fresh pepper discussed so far is based on the total production costs including family labour. However, as previously mentioned, in many cases family labour is not paid in cash, or only partly, so one could

\footnotetext{
${ }^{8}$ For each $\mathrm{kg}$ of processed black pepper, $3.33 \mathrm{~kg}$ of fresh pepper are needed.

${ }^{9}$ As explained earlier, this is in accordance with the (neo)classical microeconomic theory of monopsony, in which the profit of a monopsonist is maximised at the point that the marginal costs (of one extra kg of fresh pepper) are equal to the marginal benefits of that extra kg; see, for example, Henderson and Quandt (1980: 190-192).
} 


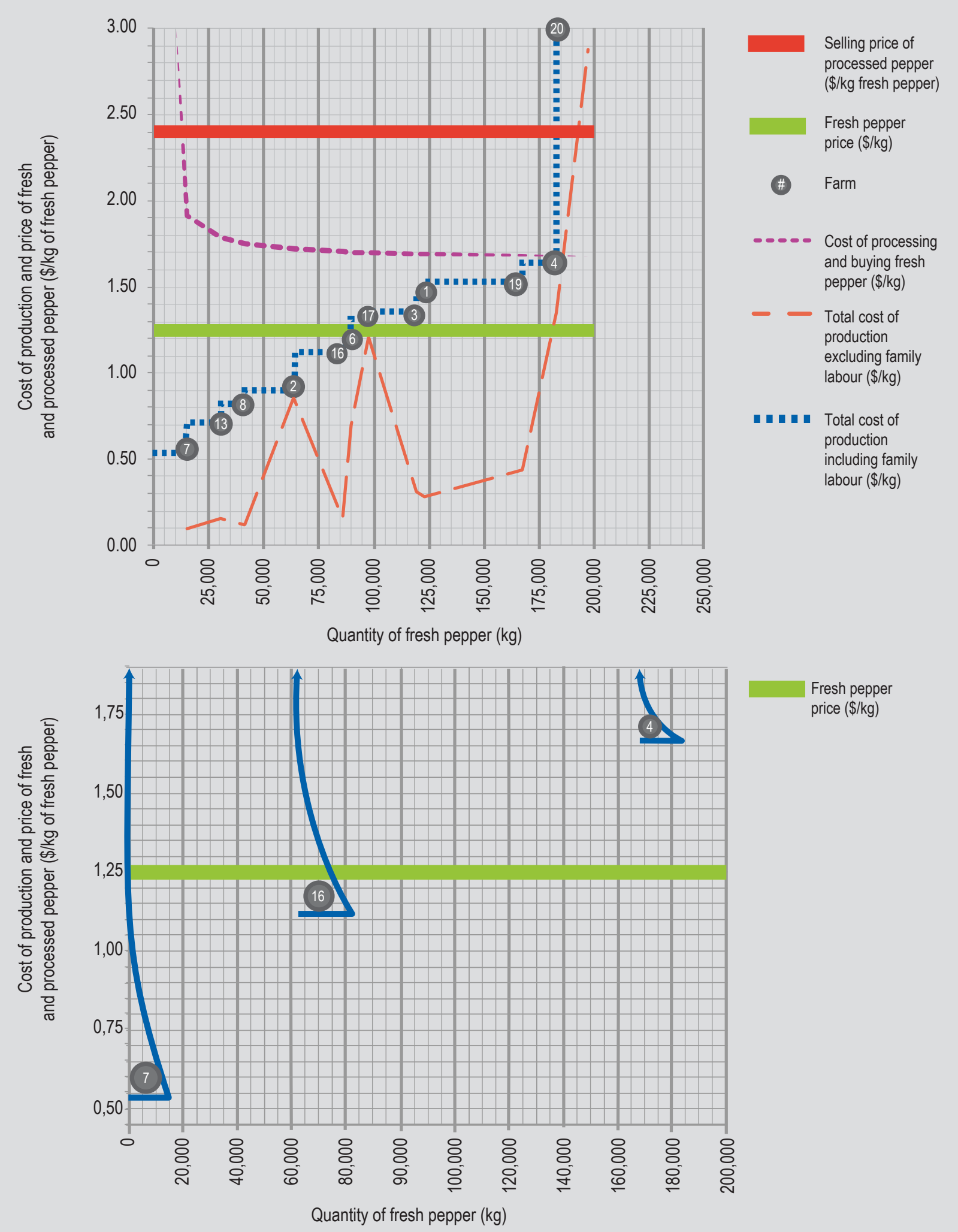

Figure 2. Quantity of produced and supplied fresh pepper (cumulatively over producers, ranked according to increasing cost of production), cost of producton and processing (both _xed and variable), and price of fresh pepper (2011, El Roble, Costa Rica). 
Table 4a. Net margin of buyer (processor) in \$ under monopsony market conditions at different prices; individual contracts (IC) only.

Price of fresh pepper in $\$ / \mathrm{kg}$

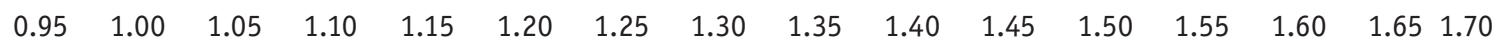

Processor 43,256 39,277 36,782 34,288 31,793 42,919 39,397 35,875 35,364 39,701 35,006 31,375 37,555 30,952 -

Table 4b. Net margin of buyer (processor) in \$ under monopsony market conditions at different prices; individual (IC) and group contracts (GC).

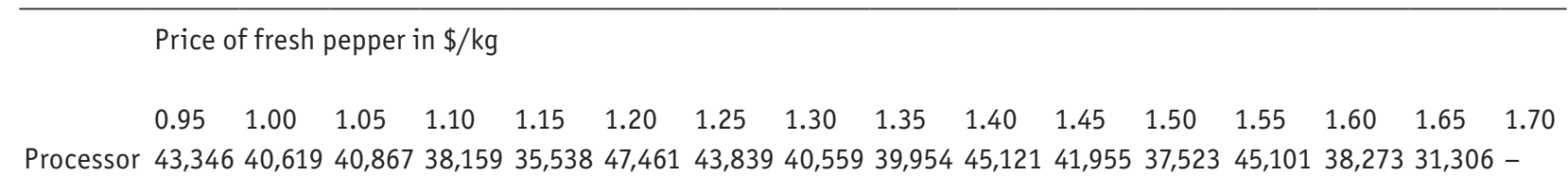

infer another supply function based on the production costs excluding family labour costs. In Figure 2, this is the striped orange line. This line is obviously always below the squared blue line. To construct a proper supply function, the farms should be arranged according to these costs of production (not done in Figure 2); however, it is clear from the figure that much more fresh pepper would be supplied to the market if famers only took into consideration the costs of production excluding family labour, rather than looking at all costs.

So far no mention has been made of fixed and variable costs of production at farm level. However, fixed costs are also important at farm level, in particular those related to the establishment of the pepper trees. At low production volumes these costs weigh heavily. Incorporating this aspect of each farm in the upper part of Figure 2 would render it too complicated, so this is illustrated in enlargements for three farms in the lower part of Figure 2. Based on 2012 survey data in combination with model simulations (Table 3), the first one (farm 7 ) has total production costs per $\mathrm{kg}$ of fresh pepper of $0.54 \$ / \mathrm{kg}$, the second (farm 16) of $\$ 1.14$ and the third (farm 4 ) of $\$ 1.66$; so at a price of $\$ 1.25$ the first and the second can produce with a profit, but the third not. However, these costs are only valid at full production capacity of each farm. If these farms do not produce that much, their production costs are (much) higher, so it is in their interests to produce as much as possible. Nevertheless, under these circumstances it might be possible that farms produce just enough to cover their fixed costs without making a profit, i.e. with a net margin of zero (this is also observed in the model results, see Table 5a and $5 \mathrm{~b}$ regarding quantities supplied, with the related net margins in Table $6 \mathrm{a}$ and $6 \mathrm{~b}$, respectively).

\section{Modelling contract choice}

Continuing with the results of the model, in this section we present the results for each scenario considered. Table $5 \mathrm{a}$ and $5 \mathrm{~b}$ show the quantity of pepper traded per farm and contract choice, at different prices, and under a monopsony market condition. In Table 5 a the results are shown if only individual contracts (IC) are possible (Scenario 1). In Table $5 \mathrm{~b}$ the results are shown if group contracts (GC) are also possible (Scenario 2). Under both market conditions it is assumed that APROPISA acts as a sole buyer of pepper for producers of El Roble. The first thing worth noting is that at each price above $\$ 1.00$ the majority of farmers can supply a slightly higher amount of pepper under group contracts than under individual contracts. This is because the rejection rate is lower, since the supplies of all farmers are combined and handled more carefully with group contracts. At each price, this also leads to a slightly higher profit for the farmers. Therefore, GC is the preferred contract choice where both parties optimise trade in order to maximize their respective net margins. When the price becomes too high for the processor (under IC \$1.65, under GC \$ 1.70), the processor only purchases fresh pepper to break even. The remainder of the supply from the producers is sold to other buyers at a discount.

It is important to remember that if APROPISA wants to increase its profits and become a well-developed enterprise, it needs more and more fresh pepper to process, and loyal 


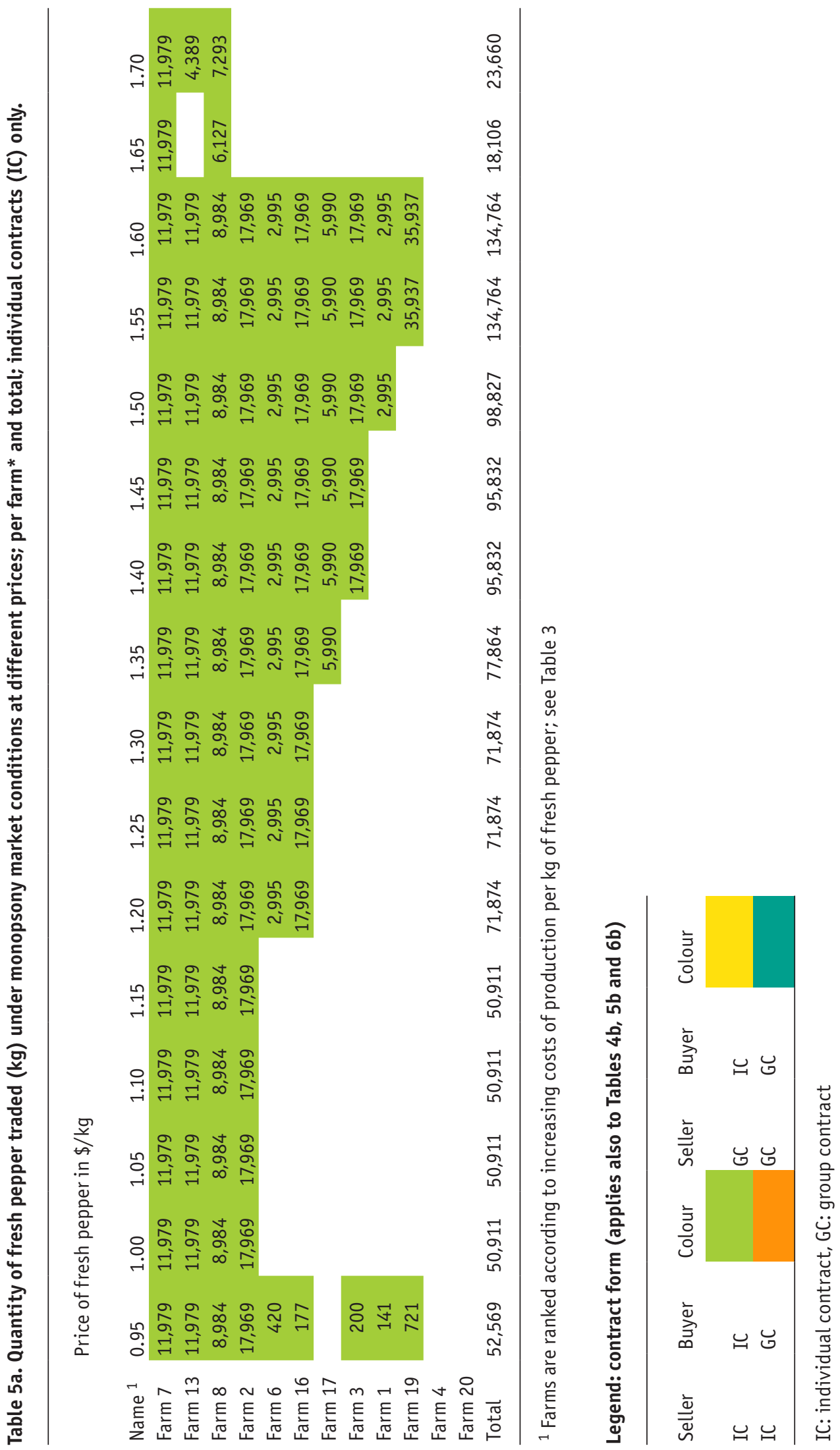




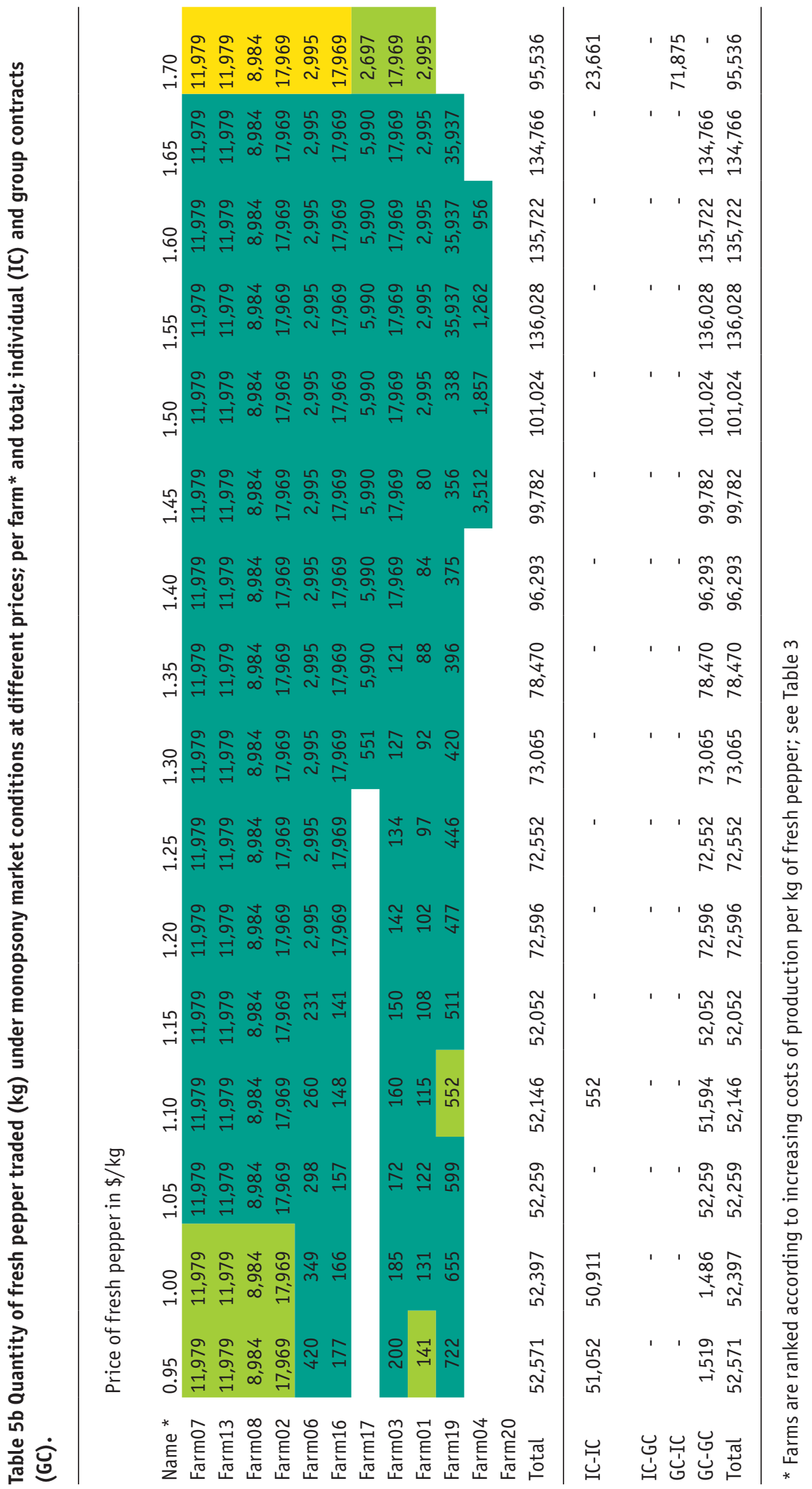




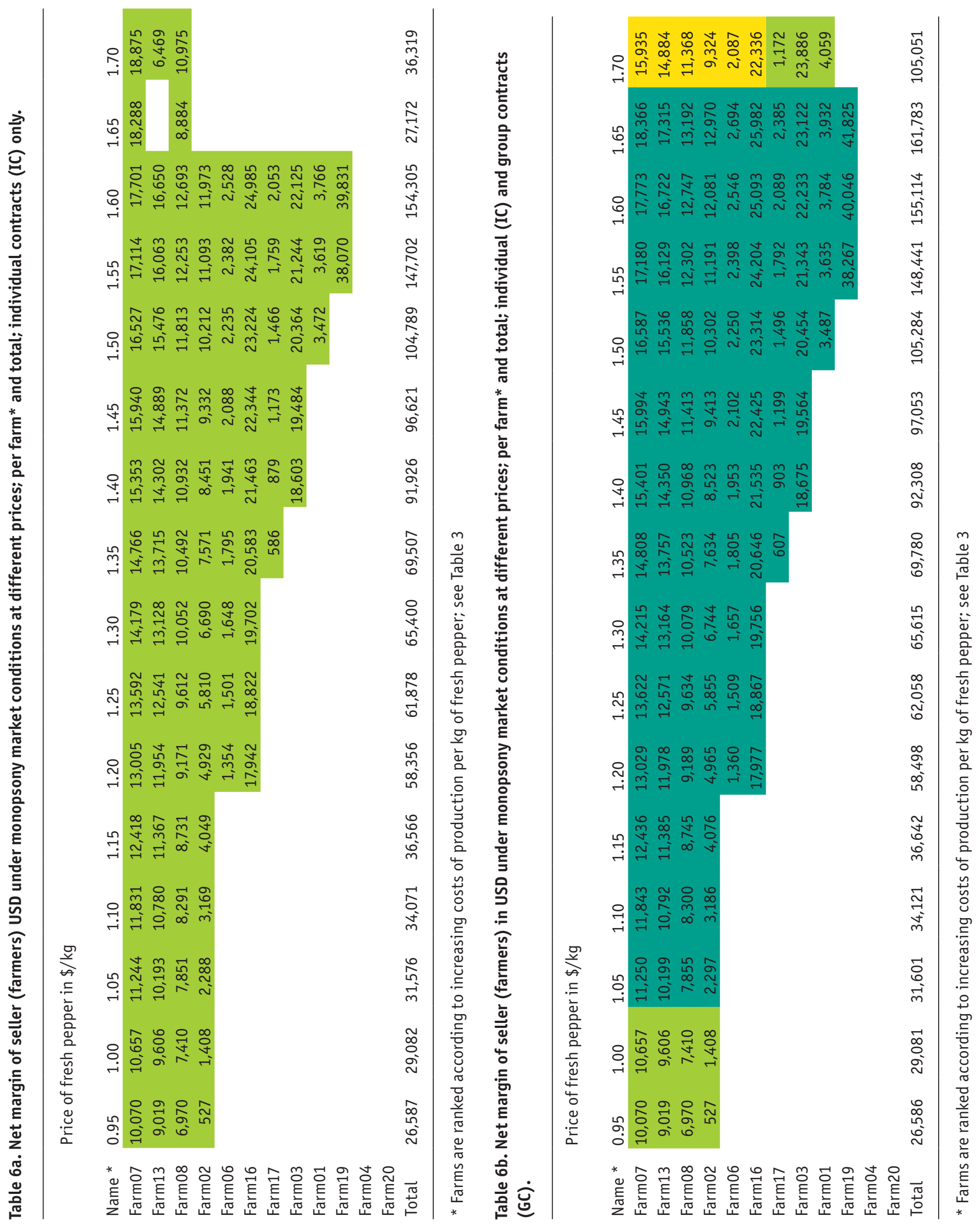


regular suppliers. In other words, members of the association occasionally selling part of their produce to other processors are certainly not in the interests of APROPISA.

Farms 19, 4 and 20 are the weakest - or most sensitive - with regard to purchase prices, because of their high production costs. Farms 4 and 20 are unable to supply pepper at a profit at any price, while Farm 19 starts making a profit at a price of $\$ 1.55$. Similarly, at lower prices there are many farmers that produce small quantities (lower than their production capacity) just to break even (if they were profit maximizers and remunerated family labour at the same rate as hired labour). Such information is important for APROPISA if the new enterprise wants to receive as much fresh pepper as possible. It could for example start a program with specific farmers to try to lower their production costs.

Based on the quantities traded in Table 5a and 5b, Table $6 a$ and $6 \mathrm{~b}$ show the net margins of the farmers under the IC only and IC and GC contract possibilities, respectively. As can be observed, at higher prices, under both conditions, the net margins of more farmers increase. Obviously, higher fresh pepper prices are very beneficial to farmers. Comparing the aggregate net surplus of the farmers under the respective contract conditions, at each fresh pepper price, farmers hardly seem to profit from GCs in comparison to IC. However, for the processor under GC conditions, it is more beneficial to offer a higher price (\$1.20) than under IC conditions ( $\$ 0.95)$, compare Table $4 \mathrm{~b}$ with Table $4 \mathrm{a}$, implying an increase in the profit of the processor from $\$ 43,256$ to 47,461 . As explained earlier, farmers benefit greatly from these $\mathrm{GC}$ at a higher price, as their aggregate net margin would increase from $\$ 26,587$ to 58,498 .

On top of that, if the processor increased the price further to $\$ 1.40$ (in case of GC), another two farmers could sell their fresh pepper without a loss (Farmers 3 and 17). In that case the total profit of the processor would decrease by $\$$ $2,340$ ( $\$ 47,461-45,121$; Table $4 \mathrm{~b})$, but the total profit of the farmers would increase by $\$ 33,810$ ( $\$ 92,308$ - 58,498; Table $6 \mathrm{~b}$ ). As the processor is an association of the farmers, the farmers could compensate the processor, e.g. by paying a higher membership fee. A similar situation occurs at a price of $1.55 \$ / \mathrm{kg}$ of fresh pepper (farmers 1 and 19 could enter the market without a loss).

\section{Conclusions}

\section{Fair procurement price, production costs and contract choice scenarios}

The perception of an 'unknown' fair procurement price between APROPISA and its supplying producers endangers the sustainability of their trade relationship. In addition, the lack of information on production and processing costs increases distrust and delays the transition from basic collective actions to a formal enterprise performing a more sustainable business.

It is in the interests of the processor to buy fresh pepper at low prices, thus lowering the processing costs. However, given the fixed costs, it is also in his interests to buy as much fresh pepper as possible in order to enlarge his own surplus. Nevertheless, the quantity of processed (black) pepper supplied to the market is determined by the supply of fresh pepper, the costs of processing, the purchase price and the transaction costs. The only way to increase the fresh pepper quantity in the short run would be to increase the fresh pepper price in order to induce more supply. Therefore, a profit-maximising processor would try to find a balance between low procurement prices and a high volume. Obviously, in the longer run, the processor could also stimulate more supply if he helps the farmers to reduce their production costs.

On the other hand, costs of production vary considerably between different farms and determine whether a given farm is able to supply fresh pepper without incurring losses. In this regard, family labour (and its remuneration) is an important variable affecting production costs. Any agreement that APROPISA may conclude with its supplying producers should take into account that family labour remuneration is not known, but is in general not supplied directly in cash and certainly not in full at the going rate. Therefore, families can supply pepper at lower prices without incurring a direct financial loss.

In terms of modelling contract choice, given the structure of pepper production costs (fixed and variable), transport and transaction costs, under monopsony market conditions, the preferred contract possibilities by both parties are group contracts. In comparison to individual contracts, both the profit of the processor and the surpluses of the farmers are higher.

At lower fresh pepper prices, some of the farmers supply just to break even. This occurs under both contract forms, albeit with different quantities under different prices. 
It is in the interests of the buyer to offer higher fresh pepper prices in order to buy and process more pepper, at lower processing costs, and thereby increase profit. Under monopsony market conditions, this is best accomplished using group contracts.

\section{Problems and opportunities for collective actions in El Roble settlement}

Collective actions, in the form of formal organizations, are a good device for strengthening small producers' bargaining power, while providing access to input and output markets. However, these producers' organizations are constrained by legal status, low labour force capacities, negative empowerment by an elite of members, lack of legitimate representation, and a recurrent dependency on external assistance (The World Bank, 2008). In addition, the lack of vision for promoting product innovation and services to members has the potential to finish off an organization.

In the case of APROPISA S.A., this organization has successfully stayed in business for the last 14 years. This is an important fact, since most start-up organizations with very few resources only usually last a short while. It is always difficult and time consuming for small-scale farmers to start a collective action. In fact, time is always the limiting factor that keeps many farmers from adopting any strategy to strengthen and develop an association or a cooperative. APROPISA S.A. not only kept going as an organization with basic functions, but also evolved into a small processing enterprise thanks to the procurement of public and private assistance and resources (human capacity building and processing infrastructure). On the other hand, this success cost a small group of the association committee members a lot of time. Yet the association has been unable to recruit more producers, while its members deviate from the commitment to deliver fresh pepper when market conditions are good. Both these situations endanger the future of the association.

In this paper we analysed contract scenarios, based on production and processing costs, where better procurement prices can be obtained for the benefit of both APROPISA and supplying producers. However, the current problem faced by APROPISA may be less about an 'unfair' procurement price and more to do with certain intangible variables, like trust in the association leaders, lack of commitment, and producer's opportunistic behaviour.

\section{References}

Barrett, C.B., M.E. Bachke, M.F. Bellemare, H.C. Michelson, S. Narayanan and T.F. Walker, 2011. Smallholder participation in contract farming: comparative evidence from five countries. World Development, 40(4): 715-730.

Carney, J. and M. Watts, 1990. Manufacturing dissent: work, gender and the politics of meaning. Africa, 60(2): 207-241.

De Janvry, A., M. Fafchamps and E. Sadoulet, 1991. Peasant household behaviour with missing markets: some paradoxes explained. The Economic Journal, 101: 1400-1417.

Devaux, A., D. Horton, C. Velasco, G. Thiele, G. López, T. Bernet and M. Ordinola, 2009. Collective action for market chain innovation in the Andes. Food Policy, 34(1): 31-38.

EARTH (Escuela de Agricultura para la Región del Trópico Húmedo), 2007. Calidad en el cultivo de pimienta. Módulo 7. Proyecto Promes (AECID-EARTH).

Ellis, F., 1988. Peasant economics, farm household and agrarian development. Cambridge University Press, Cambridge, UK.

Fafchamps, M., 2004. Market institutions in sub-Saharan Africa: theory and evidence. MIT Press, Cambridge, MA, USA.

Faure, G., H. Hocdé and E. Chia, 2011. Action research methodology to reconcile product standardization and diversity of agricultural practices: A case of farmers' organizations in Costa Rica. Action Research, 9(3): 242-260.

Glover, D.J. and K. Kusterer, 1990. Small farmers, big business: contract farming and rural development. MacMillan Press Ltd, London, UK.

Glover, D.J., 1984. Contract farming and smallholder outgrower schemes in less-developed countries. World Development, 12(1112): 1143-1157.

Glover, D.J., 1987. Increasing the benefits to smallholders from contract farming: problems for farmers' organizations and policy makers. World Development, 15(4): 441-448.

Gow, H.R., D.H. Streeter and J.F.M. Swinnen, 2000. How private contract enforcement mechanisms can succeed where public institutions fail: the case of Juhocukor a.s. Agricultural Economics, 23: 253-265.

Grosh, B., 1994. Contract farming in Africa: an application of the new institutional economics. Journal of African Economies, 3(2): 231-261.

Guaipatín, C., 2003. Observatorio MIPYME: compilación estadística para 12 países de la Región. Banco Interamericano de Desarrollo. Washington, DC, USA.

Henderson, J.M. and R.E. Quandt, 1980. Microeconomic theory: a mathematical approach. McGraw-Hill Book Co., Singapore, Singapore.

Instituto Nacional de Estadística y Censos (INEC), 2012. Directorio de Unidades Institucionales y de Establecimientos. INEC, San José, Costa Rica. 
Key, N. and D. Runsten, 1999. Contract farming, smallholders and rural development in Latin America: the organization of agroprocessing firms and the scale of outgrower production. World Development, 27(2): 381-401.

Knoeber, C.R., 1983. An alternative mechanism to assure contractual reliability. Journal of Legal Studies, 12(2): 333-343.

Kruijssen, F., M. Keizer and A. Giuliani, 2009. Collective action for small-scale producers of agricultural biodiversity products. Food Policy, 34(1): 46-52.

Le Coq, J.F., F. Sáenz Segura and Faure, G., 2014. Globalización y desafíos para la pequeña agricultura en Costa Rica: experiencias de organización y generación de servicios para el acceso a mercados. EUNA, Heredia, Costa Rica.

Little, P.D. and M.J. Watts (eds.), 1994. Living under contract: contract farming and agrarian transformation in sub-Saharan Africa. University of Wisconsin Press, Madison, WI, USA.

Oficina Internacional del Trabajo (OIT), 2009. Caribe Crisis Internacional y Políticas para las Mipymes. Oficina Regional para América Latina y el Caribe, San Isidro Lima, Peru.

Paumgarten, F., H. Kassa, M. Zida and M. Moeliono, 2012. Benefits, challenges, and enabling conditions of collective action to promote sustainable production and marketing of products from Africa's dry forests. Review Of Policy Research, 29(2): 229-250.

Porter, G. and K. Phillips-Howard, 1995. Farmers, labourers and the company: exploring relationships on a Transkei contract farming scheme. The Journal of Development Studies, 32(1): 55-73.

Rickson, R.E. and D. Burch, 1996. Contract farming in organizational agriculture: the effects upon farmers and the environment. In: Burch, D., R.E. Rickson and G. Lawrence (eds.). Globalization and agri-food restructuring - perspectives for the Australian region. Averbury, Brookfield, WI, USA, pp. 173-202.

Ruben, R. and F. Sáenz (2008). Farmers, markets and contracts. Chain integration of smallholder producers in Costa Rica. European Review of Latin American and Caribbean Studies, 85: 61-80

Ruben, R., G. Kruseman and H. Hengsdijk, 1994. Farm household modelling for estimating the effectiveness of price instruments on sustainable land use in the Atlantic zone of Costa Rica. DLV Report No. 4, AB-DLO, Wageningen, the Netherlands, 44 pp.

Sadoulet, E. and A.D. Janvry, 1995. Quantitative development policy analysis. The Johns Hopkins University Press, Baltimore, MD, USA.
Sáenz-Segura, F., 2006a. Contract farming in Costa Rica: opportunities for small holders? PhD thesis, Wageningen University, Wageningen, the Netherlands, $181 \mathrm{pp}$.

Sáenz-Segura, F., 2006b. Markets and contracts for small pepper producers: Implications for production systems and resource management. In: Sáenz-Segura, F. (ed.). Contract farming in Costa Rica: opportunities for small holders? PhD thesis, Wageningen University, Wageningen, the Netherlands, pp. 37-69.

Sáenz-Segura, F., 2006c. Potential benefits of collective actions: A simulation approach for pepper contracts in Costa Rica. In: SáenzSegura, F. (ed.). Contract farming in Costa Rica: opportunities for small holders? PhD thesis, Wageningen University, Wageningen, the Netherlands, pp. 103-144.

Sáenz-Segura, F., M. D'Haese and R.A. Schipper, 2010. A seasonal model of contracts between a monsopsonistic processor and small holder pepper producers in Costa Rica. Agricultural Systems, 103: 10-20.

Sáenz-Segura, F., M. D’Haese and S. Speelman, 2009. The influence of contract farming on small holders pepper (Piper nigrum L.) producers in Costa Rica under different market condition. Fruits, 64: 371-382.

Sánchez-Sánchez, A. and J.M. Chavez-Moreira, 2012. Caracterización de la agrocadena de la pimienta, ubicado en el distrito La Virgen, cantón de Sarapiquí. CINPE, UNA, Heredia, Costa Rica.

Siddiqui, K. (1998). Agricultural exports, poverty and ecological crisis-case study of Central American countries. Economic and Political Weekly, 33(39): A128-A136.

Singh, S., 2002. Contracting out solutions: political economy of contract farming in the Indian Punjab. World Development, 30(9): 1621-1638.

Sivaranam, K., K. Kandiannan, K.V. Peter and C.K. Thankamani, 1999. Agronomy of black pepper (Piper nigrum L.) - a review. Journal of Spices and Agronomic Crops, 8(1): 1-18.

The World Bank, 2008. World development report 2008: agriculture for development. The World Bank, Washington, DC, USA.

Torres, G., 1997. The force of irony: power in the everyday life of Mexican tomato workers. Berg, Oxford, UK, 243 pp.

Upton, M., 1996. The economics of tropical farming systems. Cambridge University Press, Cambridge, UK, 374 pp.

Welsh, R., 1997. Vertical co-ordination, producer response, and the locus of control over agricultural production decisions. Rural Sociology, 62(4): 491-507. 


\section{Appendix 1. Model specification (see Table A1, A2 and A3 for meaning of sets, variables and coefficients, respectively)}

- Objective function $(\$)$

$\operatorname{Max} A=\sum_{c d} w_{c} G B_{c d}-\sum_{c d} w_{c}$ ef $b_{c d} b f+\sum_{f c d}\left(1-w_{c}\right) N$

- Buyer's income calculations $(\$)$

- Gross income per type of contract

$$
\begin{array}{ll}
G B_{c d}=\sum_{f} e f b_{c d}\left(p b / c f b\left(1-r e f_{c}\right) X_{f c d}-\right. & \\
\sum_{f}\left(1-r e f_{c}\right)\left(p f_{c}+b c+t c b_{c}+t r_{c}\right) X_{f c d} & \forall c, d
\end{array}
$$

- Net income

$$
N B=\sum_{c d} G B_{c d}-b f
$$

- Seller's income calculation

- Gross income per type of contract for each seller

$$
G S_{f c d}=e f s_{d d} p f_{c}\left(1-r e f_{c}\right) X_{f c d}-\left(s c_{f}+t c s_{c}\right) X_{f c d} \quad \forall f, c, d
$$

- Net income per contract tupe for each seller

$$
N S_{f c d}=G S_{f c d}-Y_{f c d} s f_{f} \quad \forall f, c, d
$$

- Net income over all contract types for each seller

$$
N S T_{f}=\sum_{c d} N S_{f c d}
$$

- Minimum income requirements per period (\$)

- Buyer (to avoid infeasibilities NB is defined as a semi-continuous variable, meaning it can be 0, or between a lower and upper limit)

$$
N B \geq r i b
$$

- Sellers (to avoid infeasibilities $\mathrm{NST}_{\mathrm{f}}$ is defined as a semi-continuous variable)

$$
N S T_{f} \geq \operatorname{ris}_{f}
$$

- Capacity restriction $(\mathrm{kg})$

$\sum_{c d} X_{f c d} \leq p q_{f}$ 
- Binary part of the model
$X_{f c d} \leq m^{*} Y_{f c d}$
$\forall f, c, d$
$\sum_{c d} Y_{f c d} \leq 1$
$\forall f$

Table A1. Sets.

\begin{tabular}{lll}
\hline Symbol & Elements of set & Explanation \\
c & & Contractual arrangement (in general or as chosen by seller) \\
& IC & $\begin{array}{l}\text { Contract between individual farmer and processor } \\
\text { Contract between farmer group and processor } \\
\end{array}$ \\
d & Contractual arrangement as chosen by buyer \\
& IC & Contract between individual farmer and processor \\
& GC & Contract between farmer group and processor \\
f & Seller or farmer \\
& Farm01 to Farm20 & Individual seller or farmers \\
\hline
\end{tabular}

Table A2. Variables used in the model with units.

\begin{tabular}{lllll}
\hline Symbol & Explanation & Indices & Type of variable & Units \\
$\mathrm{A}$ & Objective variable to be maximized & & & USD \\
$\mathrm{NB}$ & Net income of buyer (processor) & $\mathrm{c}, \mathrm{d}$ & Semi-continuous & USD \\
$\mathrm{NS}_{\mathrm{fcd}}$ & Net income of each seller (farmer) & $\mathrm{f}, \mathrm{c}, \mathrm{d}$ & Free & USD \\
$\mathrm{NST}_{\mathrm{f}}$ & Total net income of each seller & $\mathrm{f}$ & Semi-continuous & USD \\
$\mathrm{X}_{\mathrm{fcd}}$ & Volume of traded fresh pepper & $\mathrm{f}, \mathrm{c}, \mathrm{d}$ & Semi-continuous & $\mathrm{Kg}$ \\
$\mathrm{F}_{\mathrm{fcd}}$ & Price of fresh pepper & $\mathrm{f}, \mathrm{c}, \mathrm{d}$ & Positive & USD $/ \mathrm{kg}$ \\
$\mathrm{GB}_{\mathrm{cd}}$ & Gross income of buyer & $\mathrm{c}, \mathrm{d}$ & Free & USD \\
$\mathrm{GS}_{\mathrm{fcd}}$ & Gross income of each seller & $\mathrm{f}, \mathrm{c}, \mathrm{d}$ & Free & USD \\
$\mathrm{Y}_{\mathrm{fcd}}$ & Binary marketing choice variable & $\mathrm{f}, \mathrm{c}, \mathrm{d}$ & Binary & \\
\hline
\end{tabular}


Table A3. Coefficients (parameters) used in the model with units.

\begin{tabular}{|c|c|c|}
\hline Symbol & Explanation & Units \\
\hline$w_{C}$ & Market power & \\
\hline $\mathrm{cfb}$ & Conversion factor of fresh pepper to black pepper & $\mathrm{kg} / \mathrm{kg}$ \\
\hline $\mathrm{pb}$ & Black pepper price & USD $/ \mathrm{kg}$ \\
\hline $\mathrm{pf}_{\mathrm{c}}$ & Fresh pepper price & USD $/ \mathrm{kg}$ \\
\hline ref & Rejection rate of fresh pepper & \\
\hline bc & Buyer's (processor) variable cost of production per kg of fresh pepper & USD $/ \mathrm{kg}$ \\
\hline bf & Buyer's fixed costs per year & USD \\
\hline $\mathrm{SC}_{\mathrm{f}}$ & Seller's (farmer) variable cost of production per kg of fresh pepper & USD $/ \mathrm{kg}$ \\
\hline$s f_{f}$ & Seller's fixed costs per year & USD \\
\hline rib & Reservation income buyer (processor) per season & USD \\
\hline ris $_{f}$ & Reservation income seller (farmer) per season & USD \\
\hline $\mathrm{tcb}_{\mathrm{c}}$ & Transaction cost of buyer & USD/kg \\
\hline $\operatorname{tcs}_{c}$ & Transaction cost of sellers & USD/kg \\
\hline $\operatorname{tr}_{\mathrm{c}}$ & Transport cost & USD/kg \\
\hline $\mathrm{efb}_{\mathrm{cd}}$ & Effect of contract choices by sellers and buyer on buyer's gross income & \\
\hline $\mathrm{efs}_{\mathrm{cd}}$ & Effect of contract choices by sellers and buyer on seller's gross income & \\
\hline $\mathrm{pq}_{\mathrm{f}}$ & Fresh pepper production capacity per farmer & $\mathrm{kg}$ \\
\hline $\mathrm{m}$ & Artificial large number to force binary solution & \\
\hline
\end{tabular}


